\title{
Phyto-Chemical Screening and Evaluation of Anti-Bacterial Activity of Ziziphus Rotundifolia Root Extract
}

Chauhan $A^{*}$ and Kumar A

Sardar Bhagwan Singh Post Graduate Bio-medical College, Balawala, Dehradun, India

\begin{abstract}
The powdered root material of Ziziphus rotundifolia was extracted with three different solvents i.e. Petroleum Ether, Chloroform and Methanol. The extract was then dried and subjected to phyto-chemical screening that showed the presence of alkaloid, steroid, terpene, glycoside and saponin in different solvent extracts. The extract was then used to explore the anti bacterial activity and it was found to be effective against Proteus vulgaris, Escherichia coli, Staphylococcus aureus and Pseudomonas aeruginosa.
\end{abstract}

\section{Introduction}

Ziziphus nummularia (W and A) a common synonym of Ziziphus rotundifolia (Jhar beri), is a thorny bush or shrub 6-8 meter high and mostly found in western India, south eastern Pakistan and south Iran. The plant is commonly found in agricultural fields [1,2].

Ziziphus nummularia the plant of family Rhamnaceae has numerous uses for animals, agriculture and medicine. It is used in traditional medicine of many Asian countries. Fruits of $Z$. nummularia are used as laxative and astringent, while its leaves are used in scabies, boils and as expectorant. In Charu (Rajasthan, India), rural people frequently used this plant for various disease conditions such as gout, rheumatism, diarrhea, fever, carbuncles, ulcers, abscess, boils and wounds as an alternate to medicine. It is used for lung inflammations and as anticongestion at the traditional Arab herbal medicine in the eastern region of the Mediterranean. This plant is also used as anti diarrheal and anti-infective for skin by local community of Jodhpur District of Thar Desert. Root bark powder mixed with cane sugar is taken with milk (3-5 g twice a day) to induce abortion in pregnant ladies. The plant is used at western Kachchh, Gujarat (India) as an ethno medicinal plants for blood purification and reduce vomiting. Anti-tumor activity is also observed for one naphthoquinone compound isolated from the plant as adjuvant for radiation therapy. Leaves and seeds of this plant are used by ethno veterinarians at Al-Qassim region, Saudi Arabia for treatment of old wound of camels. The paste of the plant leaves is also used by the ethno-veterinary medicine at the greater Cholistan desert (Pakistan) to cure the itch and chronic ulcerous wound in animals. The plant is being used as anti helmentic in Pakistan. Methanolic extract of the aerial parts of this plant showed antioxidant, antibacterial and antifungal activities. The plant is widely used in food, fuel, fodder, medicine and erosion control [1-14].

The literature survey reveals that most of the research work has been conducted on leaves, fruit and stem. The root of the plant remains unexplored for its phyto-chemical and bio-medical potential and their applications. So, it was decided to extract the powdered root with three different solvents and explore its anti-bacterial activity both with gram positive and negative bacteria (Table 1).

\section{Materials and Method}

\section{Sample collection}

The sample was collected from adjoining area of Dhampur, Dist. Bijnor (U.P.) in India. It was identified by Dr. S. A. S Biswas, Head of the Department, Botany, Forest Research Institute, Dehradun in Uttrakhand in November 2000.

\section{Sample Extraction}

The plant material was dried at $45^{\circ} \mathrm{C}$ in hot air oven. The roots were powdered in iron mortar and pestle. $1 \mathrm{~kg}$ of the crushed root was successively extracted from the soxhlet assembly by three solvents namely petroleum ether $\left(40-60^{\circ} \mathrm{C}\right)$, chloroform and methanol. The extracts were preserved in the desiccators in dark place.

\section{Phyto-chemical screening}

The extract obtained was tested for alkaloids, saponins, sterol \& terpenes, tannins, proteins and glycoside as per the methods reported earlier [15-17].

Test for alkaloids: A portion of the extract was made acidic with dilute sulphuric acid and the acidic extract was divided into two parts. With Mayer's reagent it gives while ppt for positive test. With Dragendorff's reagent it gives orange brown ppt. for the positive test.

Test for saponins: A small amount of the extract was boiled with water and allowed to cool. It was shaken vigorously in a test tube and left for a few minutes. The formation of persistent honey comb like froth was taken as a positive test.

Test for sterols and terpenes: A small amount of the extract was evaporated to dryness and extract was dissolved in $3 \mathrm{ml}$ of chloroform. The filtrate was treated with three drops of a mixture of concentrated

\begin{tabular}{|c|c|c|c|}
\hline S.No & Solvent & Hours of extraction & Weight of extract \\
\hline $\mathbf{1}$ & Petroleum ether & 35 & $4.5 \mathrm{~g}$ \\
\hline 2 & Cholorofom & 33 & $13.0 \mathrm{~g}$ \\
\hline 3 & Methanol & 32 & $19.0 \mathrm{~g}$ \\
\hline
\end{tabular}

Table 1: The details of soxhlet extraction.

*Corresponding author: Chauhan A, Sardar Bhagwan Singh Post Graduate Bio-medical College, Balawala, Dehradun, India, Tel: 919464616773; E-mail: aashishchauhan26@gmail.com

Received December 18, 2014; Accepted February 23, 2015; Published March 02, 2015

Citation: Chauhan A, Kumar A (2015) Phyto-Chemical Screening and Evaluation of Anti-Bacterial Activity of Ziziphus Rotundifolia Root Extract. Pharm Anal Acta 6: 344. doi:10.4172/2153-2435.1000344

Copyright: (c) 2015 Chauhan A, et al. This is an open-access article distributed under the terms of the Creative Commons Attribution License, which permits unrestricted use, distribution, and reproduction in any medium, provided the original author and source are credited. 
sulphuric acid and acetic anhydride. The production of different shade of color was recorded as a positive test.

It was furthered verified by Libermann Buchard test. A small portion of the extract was treated with hot acetic anhydride, cooled and then few drops of concentrated sulfuric acid were added, Production of bluish green color confirmed sterol while violet or pink for terpene.

Test for tannins: A small amount of the extract was treated with $5 \%$ ferric chloride solution and the production of green to blue color was taken as a positive test for tannins.

Test for proteins: Addition of very dilute copper sulphate to alkaline solution of protein gives red to violet solution that confirms protein by Biuret test. Protein produces yellow orange color when warmed with concentrated nitric acid and color gets orange when made alkaline in Xantho proteins test. Millon's reagent gives white ppt. when a solution of mercuric nitrate containing nitrous acids is added to a protein solution.

Test for carbohydrates: Molish test is positive when on treatment with alpha napthol and concentrated sulphuric acid the extract gives purple color. Reduction of Fehling's solution is seen when in a solution of carbohydrate equal quantity of Fehling A and B are added. After heating brick red ppt. is obtained. In Benedict's test, the test solution gave yellow or reddish brown precipitate with Benedict's reagent after boiling on water bath.

\section{Anti-bacterial activity}

The assay medium components are given in the table 2 . The antibacterial activity was observed against the following bacteria. The bacterial culture was maintained on nutrient agar slants stored at $4^{\circ} \mathrm{C}$ refrigerator.

\section{Proteus vulgaris}

1. Escherichia coli

2. Alcaligens faecalis

\begin{tabular}{|c|c|c|}
\hline S. No & Components & Quantity (g/L) \\
\hline $\mathbf{1}$ & Peptone & 05.0 \\
\hline $\mathbf{2}$ & Beef extract & 03.0 \\
\hline $\mathbf{3}$ & Sodium chloride & 05.0 \\
\hline $\mathbf{4}$ & Agar-Agar & 15.0 \\
\hline
\end{tabular}

Table 2: Composition of the medium.

\begin{tabular}{|c|c|c|c|c|c|}
\hline $\mathrm{Sr}$ & $\begin{array}{l}\text { Plant } \\
\text { Constituents }\end{array}$ & Test Performed & $\begin{array}{l}\text { Petroleum } \\
\text { ether extract }\end{array}$ & $\begin{array}{l}\text { Methanol } \\
\text { Extract }\end{array}$ & $\begin{array}{l}\text { Chloroform } \\
\text { extract }\end{array}$ \\
\hline 1 & $\begin{array}{l}\text { Carbohydrate \& } \\
\text { Glycoside }\end{array}$ & $\begin{array}{l}\text { Benedict test } \\
\text { Fehling's test } \\
\text { Molisch test }\end{array}$ & $\begin{array}{l}- \\
- \\
-\end{array}$ & $\begin{array}{l}+ \\
- \\
-\end{array}$ & $\begin{array}{l}- \\
- \\
-\end{array}$ \\
\hline 2 & Protein & $\begin{array}{l}\text { Xanthoprotic test } \\
\text { Millon's test } \\
\text { Biuret test }\end{array}$ & $\begin{array}{l}- \\
- \\
-\end{array}$ & $\begin{array}{l}- \\
- \\
-\end{array}$ & $\begin{array}{l}- \\
- \\
-\end{array}$ \\
\hline 4 & Alkaloid & $\begin{array}{l}\text { Mayer test } \\
\text { Dragondroff test }\end{array}$ & - & + & - \\
\hline 6 & Steroid & $\begin{array}{l}\text { Liberman } \\
\text { Buchard test } \\
\text { Salkowaski test }\end{array}$ & $\begin{array}{l}+ \\
+\end{array}$ & $\begin{array}{l}+ \\
+\end{array}$ & $\begin{array}{l}+ \\
+\end{array}$ \\
\hline 8 & Tannin & Ferric chloride test & - & - & - \\
\hline 9 & Saponin & Foam test & _ & + & - \\
\hline
\end{tabular}

where, - refers to its absence and + refers to the presence of the metabolite in the extract.

Table 3: The qualitative chemical analysis of metabolites presents in root extract of Zizyphus Numularia.

\section{Bacillus cereus \\ 4. Schiegella dysenterae \\ 5. Staphylococcus aureus \\ 6. Pseudomonas aeruginosa}

The medium was prepared by dissolving the content in 1000 $\mathrm{ml}$ distilled water at $\mathrm{pH}$ 7.0. The distribution and sterilization of medium was done as per experimental requirements and followed the methodology as given by Aneja [18].

\section{Anti-bacterial assay}

Preparation of agar plates: $25 \mathrm{ml}$ of molten nutrient agar medium cooled to $45^{\circ} \mathrm{C}$ was added into pre sterilized petriplates and was allowed to solidify. Petri plates were allowed to dry by placing them at $37^{\circ} \mathrm{C}$ for 35 minutes. $0.1 \mathrm{ml}$ of 16 hours old culture of microbial strains was swabbed over the agar plates.

Preparation of filter paper discs: Six mm diameter filter paper discs were prepared and impregnated with plant extract. Dried discs were placed in seeded agar petriplates at equal distance and incubated at $37^{\circ} \mathrm{C}$ for $16-20$ hours. The methanolic extract was used to test the anti-bacterial activity.

\section{Results and Discussion}

\section{Phyto-chemical screening}

The results obtained by qualitative phyto-chemical screening for primary and secondary metabolites in the root extracts have been summarized below in table 3 .

The results obtained clearly show that the methanol roots extract has phyto-chemical constituents like glycoside, saponin, alkaloids and steroids. The phyto-chemical analysis of the roots of $Z$. nummuleria remains unexplored as yet but the result obtained after screening the chemical metabolites (primary and secondary) are similar to the results obtained earlier for the phyto-chemical screening of leaves, fruits of $Z$. nummularia [19].

\section{Anti-bacterial property}

The result obtained by anti bacterial assay clearly suggests that the methanolic extract is effective against $P$. vulgaris, E. coli, $S$. aureusm and $P$. aeruginosa as seen in table 4 .

The anti-microbial potential of the root extract of $Z$. nummularia has not been taken up for study so far but the results obtained are similar to that reported for leaf extract, earlier. The extract is effective against both gram positive and negative bacteria [20,21].

\section{Conclusions}

Ziziphus rotundifolia has numerous applications. The root extract was obtained by using three different solvents i.e. Petroleum Ether, Chloroform and Methanol. The extract was then subjected to phytochemical screening that showed the presence of alkaloid, steroid, terpene, glycoside and saponin. The extract was then used to explore the anti bacterial activity and it was found to be effective against both gram positive and gram negative bacteria such as Proteus vulgaris, Escherchia coli, Staphylococcus aureus and Pseudomonas aeruginosa.

\section{Acknowledgement}

I am grateful to the guidance of my mother Mrs. Madhvi Chauhan, Sisters Mrs. Sushma Singh and Mrs. Sapna Chauhan for being a support. I am indebted 
Citation: Chauhan A, Kumar A (2015) Phyto-Chemical Screening and Evaluation of Anti-Bacterial Activity of Ziziphus Rotundifolia Root Extract. Pharm Anal Acta 6: 344. doi:10.4172/2153-2435.1000344

Page 3 of 3

\begin{tabular}{|c|c|c|c|}
\hline S. No. & Bacterial Culture & Gram reaction & $\begin{array}{c}\text { Inhibition zone } \\
\text { (Diameter in } \mathbf{~ m m} \text { ) }\end{array}$ \\
\hline 1 & Proteus vulgaris & $-\mathrm{ve}$ & 10.0 \\
\hline 2 & Escheria coli & $-\mathrm{ve}$ & 8.0 \\
\hline 3 & Staphylococcus aureus & $+\mathrm{ve}$ & 8.0 \\
\hline 4 & Pseudomonas aeruginosa & $-\mathrm{ve}$ & 6.0 \\
\hline 5 & Alcaligens faecalis & $-\mathrm{ve}$ & - \\
\hline 6 & Bacillus cerus & $+\mathrm{ve}$ & - \\
\hline 7 & Schigella dysentrae & -ve & - \\
\hline
\end{tabular}

Table 4: Account of the anti-bacterial activity of the methanolic root extract.

to my wife Mrs. Priyanka Chauhan and son Master Praver Chauhan for their perseverance and patience to bear the hardships in my busy schedules.

I am liable to express the greatness of Dr. Gajraj Bist, Department of Microbiology, SBSPGI, Balawala, Dehradun for conducting the anti bacterial activity.

\section{References}

1. Chadha YR (1948) The Wealth of India and Cumulative Indexes, X-Z, CSIR, New Delhi, X-Z 33-124.

2. Kokate CK, Purohit AP, Gokhale SB (1998) Pharmaconosy, Nirali Prakashan, 15: $1-58$

3. Abbas B, Al-Qarawi AA, Al-Hawas A (2002) The ethnoveterinary knowledge and practice of traditional healers in Qassim Region, Saudi Arabia. J Arid Environ 50: 367-379.

4. Azaizeh H, Saad B, Khalil K, Said O (2006) The state of the art of traditional Arab herbal medicine in the Eastern region of the Mediterranean: A review. Evid Based Complement Alternat Med 3: 229-235.

5. Bachaya HA, Iqbal Z, Khan MN, Sindhu ZU, Jabbar A (2009) Anthelmintic activity of Ziziphus nummularia (bark) and Acacia nilotica (fruit) against Trichostrongylid nematodes of sheep. J Ethnopharmacol 123: 325-329.

6. Baie S, Sheikh KA (2000) The wound healing properties of Channa striatus cetrimide cream-wound contraction and glycosaminoglycan measurement. $J$ Ethnopharmacol 73: 15-30.
7. Chanda S, Dave R, Kaneria M (2011) In vitro antioxidant property of some Indian medicinal plants. Res J Med Plant 5: 169-179.

8. Chawla AS, Kaith BS, Handa SS, Sharma AK, Balbir SK (1987) Plant antiinflammatory agents. J Sci Ind Res 46: 214-223.

9. Kaith BS, Kaith NS, Chauhan NS (1996) Anti-inflammatory effects of Arnebia euchroma root extract. J Ethnopharamacol 55: 77-80.

10. Khan FM (2009) Ethno-veterinary medicinal usage of flora of greater Cholistan desert (Pakistan). Pak Vet J 29: 75-80.

11. Leite SN, Palhano G, Almeida S, Biavatti MW (2002) Wound healing activity and systemic effects of Vernonia scorpioides extract in guinea pig. Fitoterapia 73: 496-500.

12. Shah AH, Khan RMA, Maurya SK, Singh VP (1989). Nummularine-s: A cyclopeptide alkaloid from stem bark of Zizyphus nummularia. Phytochemistry, 28: 305-307.

13. Srivastava SK (1984) Nummularogenin, a new spirostane from Zizyphus nummularia. J Nat Prod 47: 781-783.

14. Ullah R, Hussain Z, Iqbal Z, Hussain J, Khan FU (2010) Traditional uses of medicinal plants in Darra Adam Khel NWFP Pakistan. J Med Plants Res 4 1815-1821.

15. Chopra RN, Chopra K, Handa K L,Kapoor L D (1958) Indigenous Drugs of India, $2^{\text {nd }}(\mathrm{edn})$, Academics Publisher, Calcutta.

16. Finar IL (1994) Organic Chemistry, 2 (5) ELBS Long Mann Publishers, 517.

17. Kokate CK (2000) Pharmacognosy, Nirali Publications, pp-114.

18. Aneja KR (2001) Experiment in Microbiology, Plant Pathology Tissu Culture and Muchroom Cultivation, Vishva Prakashan, New Delhi, 3: 317-320.

19. Sharma SK, Singh J, Maherchandani S, Kashyap SK (2012) Antibacterial Activity of Zizyphus nummularia and Prosopis cineria leaves extracts against Staphylococcus aureus and Escherichia coli. Veterinary Practitioner 13: 46-48.

20. Sumitra C, Mital K, Yogesh Kumar V (2011) Evaluation of Antimicrobial potential of some of the Indian Medicinal plants against some pathogenic microbes. Indian Journal of Natural Products and Resources 2: 225-228.

21. Waqar ahmad Kaleem, Naveed Muhammad, Haroon Khan, Abdur Rauf (2014) Pharmacological and Phyto chemical studies of Genus Zizyphus, Middle East Journal of Scientific Reseach, 21: 1243-1263. 